\title{
High-use areas, seasonal movements and dive patterns of juvenile loggerhead sea turtles in the Southwestern Atlantic Ocean
}

\author{
Caren Barceló ${ }^{1,3,5, *}$, Andrés Domingo ${ }^{2}$, Philip Miller ${ }^{3}$, Leonardo Ortega ${ }^{2}$, \\ Bruno Giffoni ${ }^{4}$, Gilberto Sales ${ }^{4}$, Lianne McNaughton ${ }^{5}$, Maria Marcovaldii ${ }^{4}$, \\ Selina S. Heppell ${ }^{1}$, Yonat Swimmer ${ }^{6}$ \\ ${ }^{1}$ Department of Fisheries and Wildlife, Oregon State University, 104 Nash Hall, Corvallis, Oregon 97331, USA \\ ${ }^{2}$ Dirección Nacional de Recursos Acuáticos, Constituyente 1497, Montevideo 11200, Uruguay \\ ${ }^{3}$ Centro de Investigación y Conservación Marina (CICMAR), Av. Giannattasio km. 30,500, El Pinar, Canelones 15008 , \\ Uruguay \\ ${ }^{4}$ Projecto TAMAR, Fundação Pró Tamar / ICMBio, Salvador, Bahia 2219, Brazil \\ ${ }^{5}$ Joint Institute for Marine and Atmospheric Research, University of Hawaii, 1000 Pope Road, Honolulu, Hawaii 96822, USA \\ ${ }^{6}$ NOAA Fisheries, 501 W. Ocean Blvd., 4200 Long Beach, California 90802, USA
}

\begin{abstract}
Characterizing the behaviors of sea turtles and identifying high-use areas as they vary in time and space is important for conservation planning, particularly when turtles overlap with fisheries that may unintentionally harm them. Between July 2006 and March 2010, 27 satellite transmitters were deployed at sea on juvenile loggerheads Caretta caretta captured as bycatch in the Uruguayan and Brazilian pelagic longline fisheries operating in the Southwestern Atlantic Ocean. Tracking duration ranged from 3 to $639 \mathrm{~d}$ (mean \pm SD: $259 \pm 159 \mathrm{~d}$; $\mathrm{n}=27$ ), during which turtles moved between latitudes of 25 to $45^{\circ} \mathrm{S}$ and longitudes 35 to $54^{\circ} \mathrm{W}$. High-use areas for the tracked turtles were over the continental shelf and slope within the Uruguayan, Argentinian, and Brazilian exclusive economic zones and in adjacent international waters. Diving information was available for 5 turtles. The maximum dive depth recorded varied between 100 and $300 \mathrm{~m}$. Two turtles demonstrated potential bottom-feeding behaviors by diving to depths that corresponded closely with the depth of the seafloor $(<200 \mathrm{~m})$ at their given location. The sea surface temperature encountered by tagged turtles was on average $19.8 \pm 2.3^{\circ} \mathrm{C}$ (range: 10.2 to $28.4^{\circ} \mathrm{C}$ ), and turtles showed an affinity for waters supporting moderate to high primary productivity levels $\left(0.43 \pm 0.89 \mathrm{mg} \mathrm{m}^{-3}\right.$ chlorophyll a). Latitudinal movements varied by season and sea surface temperature. These findings, along with those of other studies conducted in the region, demonstrate the need to strengthen ongoing collaborative efforts between neighboring countries and other international partnerships to further the research and management of sea turtles in this area.
\end{abstract}

KEY WORDS: Satellite tracking $\cdot$ Juvenile $\cdot$ High-use areas $\cdot$ Seasonal variations $\cdot$ Pelagic longline fishery $\cdot$ Remote sensing

\section{INTRODUCTION}

The loggerhead sea turtle Caretta caretta (Linnaeus, 1758) is distributed widely in the tropical, subtropical, and warm-temperate waters of the world's oceans and occupies a range of habitat types (Dodd 1988). This species has a prolonged and complicated developmental life history and is listed by IUCN as endangered over its entire distribution (IUCN 2012). The study of loggerhead sea turtles is extensive, but 
there are still significant gaps in our knowledge about their ecology and behavior at sea, particularly in the southern hemisphere.

The presence of loggerhead sea turtles in the Southwestern Atlantic (SWA) has been reported for close to 90 yr (Murphy 1914, Freiberg 1945) due to their occurrence in fishing gear, strandings, and nesting events. In the South Atlantic, the primary nesting beaches are located along the mainland coast of Brazil (Marcovaldi \& Chaloupka 2007). The majority of the nesting occurs in the state of Bahia, followed by nesting in Espírito Santo, Rio de Janeiro, and Sergipe. From almost 3 decades of tag-recapture data, the reproductive biology and adult female movements are well defined for Brazilian loggerheads (Marcovaldi et al. 2000, 2010). Adult female C. caretta are known to reach southern foraging regions along the Uruguayan coast and Rio de la Plata estuary as well as over to the Azores Islands in the North Atlantic (Marcovaldi et al. 2000, Laporta \& Lopez 2003). Recently, satellite telemetry has provided insight into the inter- or post- nesting migratory routes, habitat use, and high-use areas of adult female loggerheads from the state of Bahia along the northern coast of Brazil (Marcovaldi et al. 2010). While adults have been extensively studied in this region, much less is known about the ecology of juveniles in this part of the world.

The life history and behaviors of loggerhead sea turtles are considerably more complex than previously thought. The classic life-history model proposes that after swimming away from nesting beaches as hatchlings, small juveniles spend more than a decade in the oceanic environment, actively swimming as well as passively drifting (Bolten 2003). This conceptual model also presumes that immature oceanic loggerheads at a certain size undergo an ontogenetic shift and move from the oceanic to neritic habitats to maximize growth potential (Musick \& Limpus 1997, Bjorndal et al. 2000). In contrast, there are numerous examples of both adult and juvenile stage loggerheads exhibiting a diversity of foraging and migratory strategies. For example, juveniles in the North Pacific forage both in the central North Pacific and in neritic habitats off the coast of the Baja California Peninsula, Mexico (Peckham et al. 2007, 2011, Howell et al. 2010). Also, those in the North Atlantic Ocean have been found to return to oceanic habitats after spending time in the coastal neritic region, which suggests that the ontogenetic shift in this region is actually facultative and reversible (McClellan \& Read 2007, Mansfield et al. 2009, McClellan et al. 2010). Until now, there has been no available data describing the movements and behaviors of juvenile loggerheads in the SWA, which has unique physical features that likely influence patterns of behavior and habitat use through the turtles' development.

The ability to answer questions regarding the behavior of marine vertebrates in the open ocean has greatly increased with the latest advancements in technology, as is evidenced by a vast array of satellite telemetry and other tools for research (Hart \& Hyrenbach 2009). Satellite tags have been used to track the movements of sea turtles since the 1980s, with an exponential increase in the number of studies and turtles tagged in recent years (Godley et al. 2008). Satellite telemetry and remote sensing have assisted in identifying and characterizing some oceanic regions used by juvenile loggerheads in the North Pacific Ocean (Peckham et al. 2007, 2011, Kobayashi et al. 2008, 2011), in the Northwestern and midAtlantic (Bolten 2003, McClellan \& Read 2007, Mansfield et al. 2009), and in the Mediterranean (Bentivegna et al. 2007, Revelles et al. 2007, Cardona et al. 2009). Oceanographic variables such as sea surface temperature (SST), chlorophyll a ( $\mathrm{chl} a)$, mesoscale eddies and frontal regions have been found to be key variables that characterize the pelagic habitat of loggerhead sea turtles in the North and equatorial Atlantic Ocean as well as the North Pacific Ocean (Kobayashi et al. 2008, Mansfield et al. 2009).

While most satellite-tracking studies have focused on adult female turtle movement, due to the ease of satellite deployment on nesting beaches, there are a growing number of studies on the underrepresented majority of the population, specifically adult males and juveniles (Godley et al. 2008). Recent findings suggest some similarities between the major life stages: both adults and juveniles demonstrate dichotomous migratory vs. resident behavior, clearly differentiated neritic vs. oceanic habitat use, and seasonal movement patterns (reviewed by Godley et al. 2008). Foraging area use and site fidelity is a critical element of sea turtle biology that needs to be described to maximize conservation efforts (Wallace et al. 2010). Within some populations of adult female loggerheads, dichotomous foraging habitat utilization has been identified and linked to body size (Hawkes et al. 2006, Hatase et al. 2010; however, see Rees et al. 2010), with small females utilizing oceanic habitats and larger females utilizing neritic habitats (Hatase et al. 2002, 2007, Hawkes et al. 2006). The neritic vs. oceanic foraging habitat fidelity has also been identified in juvenile loggerheads. For example, Peckham et al. $(2007,2011)$ found movement 
patterns of juvenile loggerheads that were restricted to the neritic habitat of the Baja California Peninsula, Mexico, whereas juveniles are also known to inhabit a broad swath of the oceanic Central North Pacific (Howell et al. 2008, Kobayashi et al. 2008). In the Mediterranean Sea, there may also be a duality in the foraging habitats (oceanic or neritic) preferred by juvenile loggerheads. Some satellite tracking studies of loggerheads in oceanic waters of the southwestern Mediterranean have found that juveniles infrequently approach the eastern coast of mainland Spain (Cardona et al. 2005, Revelles et al. 2007), whereas other studies have revealed that some juveniles avoid the oceanic realm and instead make extensive use of the neritic habitat (Cardona et al. 2009). Peckham et al. (2011) compared 2 foraging strategies in juvenile loggerheads in the Pacific using a demographic model and hypothesized that the neritic strategy offers the potential for faster growth and ultimately higher fecundity, whereas the oceanic strategy may be a slower but safer life-history strategy. The mechanisms that produce and uphold this diversity in movement patterns of both adults and juveniles are presently unknown (Hatase et al. 2010) yet may be guided by various ecological trade-offs.

Using a variety of research methods, such as aerial and shipboard surveys, flipper tag returns, and satellite-telemetry, seasonal movement patterns have been described for both adult and juvenile loggerhead turtles in the North Atlantic (Plotkin \& Spotila 2002, Dodd \& Byles 2003, Hopkins-Murphy et al. 2003, Hawkes et al. 2006, 2007, Mansfield et al. 2009), for subadult loggerhead turtles in the North Pacific (Polovina et al. 2004, 2006), and for adults in the Mediterranean (e.g. Bentivegna 2002). Thermal conditions are likely cues for seasonal movement, along with other environmental features (e.g. primary productivity and prey availability) (Godley et al. 2008).

Understanding the relationship between sea turtle movements and habitat is important for the conservation of these endangered species as efforts are underway for dynamic management of species in response to ecosystem variables. Multiple studies have implicated pelagic longline fisheries as an important threat to immature loggerhead sea turtle populations in various regions of the world (Lewison \& Crowder 2007, Howell et al. 2008, Pons et al. 2010, Alfaro-Shigueto et al. 2011). Impacts to this age class is of particular conservation concern given that population models for loggerhead turtles indicate that the survival rate of large juvenile loggerheads has a large effect on the population growth rate of the species (Crouse et al. 1987, Heppell 1998, Heppell et al. 2005).
The Brazilian and Uruguayan pelagic longline fisheries operate in an extended portion of the SWA, and their principal target species are swordfish Xiphias gladius, tunas Thunnus obesus, T. alalunga, and T. albacares, and blue shark Prionace glauca (Mora \& Domingo 2006). These fisheries also have high sea turtle bycatch rates, principally of immature loggerhead turtles with a mean curved carapace length (CCL) of $58.9 \mathrm{~cm}$ (range: 32 to $109 \mathrm{~cm}$ ) (Giffoni et al. 2008, Sales et al. 2010).

In order to effectively reduce the impact of fisheries bycatch, we need to improve our understanding of how turtles utilize their dynamic marine habitats (Godley et al. 2008), specifically by providing an oceanographic characterization of the distribution patterns of juvenile loggerhead turtles during different seasons, when temperatures and water conditions vary. The aims of the present study were to characterize the broad scale behavioral patterns, inter-seasonal variability, and general high-use areas for immature loggerhead turtles in the SWA by using satellite telemetry of turtle movements and remotely sensed oceanographic data.

\section{MATERIALS AND METHODS}

\section{Turtle, transmitter, and satellite data}

Onboard scientific observers of PNOFA-DINARA (the National Program of Scientific Observers Onboard the Tuna Fleet) (Mora \& Domingo 2006) and Projeto TAMAR-ICMBio (the national Brazilian sea turtle conservation program) (Marcovaldi \& Marcovaldi 1999) deployed a total of 27 satellite transmitters on loggerhead sea turtles incidentally captured in Brazilian and Uruguayan pelagic longline fisheries operating in the SWA between July 2006 and November 2009. For a characterization of the Brazilian and Uruguayan longline fisheries, see Sales et al. (2008), Jimenez et al. (2009), Pons et al. (2010). Baits most often used are squid Illex argentinus and different species of mackerel (mainly Scomber spp. but also Trachurus spp.) (Mora \& Domingo et al. 2006, Sales et al. 2008).

The protocol was to bring captured sea turtles on to the vessel for measurements and attachment of a transmitter. The CCL of turtles was measured following Bolten (1999). Turtles were evaluated prerelease, and the body condition was noted. Sex was not determined as it was not externally evident due to the small size of the turtles. To prepare turtles for satellite tag attachment, the second central carapa- 
cial scute mount region was cleaned of epibiota, wiped down with ethanol, lightly sanded, and allowed to air dry. Satellite tags were adhered to the turtles using quick drying 2-part epoxies, Poxipol ${ }^{\mathrm{TM}}$ (Uruguay) and Durepoxi ${ }^{\mathrm{TM}}$ (Brazil), and allowed to dry for $30 \mathrm{~min}$ to $1 \mathrm{~h}$ on deck before release of the turtle. ARGOS-linked Telonics platform transmitter terminals (PTTs), models ST-18 and ST-20, were attached to 5 and 6 turtles, respectively, on Brazilian vessels. ARGOS-linked Wildlife Computers PTTs, models SPLASH and SPOT 5, were attached to 6 and 10 turtles, respectively, on Uruguayan vessels. Transmitters had 3 different duty cycles: (1) no duty cycle, continuous transmissions with daily transmit allowance set to 300 transmissions $\mathrm{d}^{-1}$, (2) $24 \mathrm{~h}$ on, $24 \mathrm{~h}$ off, with the daily transmit allowance set to 250 transmissions $\mathrm{d}^{-1}$, and (3) $12 \mathrm{~h}$ on, $2.5 \mathrm{~d}$ off with the daily transmit allowance set to 200 transmissions $\mathrm{d}^{-1}$. Differences in duty cycle were accommodated in the analysis by daily interpolation of location fixes (described below).

\section{Horizontal movements}

ARGOS assigns location accuracy estimates (location class [LC]) to each reported location that are classified as $1-3,0, A, B$, or $Z$, where locations with LC between 1 and 3 have estimated associated errors of $<1500 \mathrm{~m}$ of the tag's actual position (CLS 2007, Witt et al. 2010). Tracking (transmitted locations up to 24 March 2010) and remote sensing data were downloaded and filtered using the Satellite Tracking and Analysis Tool (STAT) (Coyne \& Godley 2005) program available from http://seaturtle. org. For the present study, we included the first location received during a $24 \mathrm{~h}$ period in order to reduce spatial autocorrelation (De Solla et al. 1999, James et al. 2005, Mansfield et al. 2009). We chose to include only LC classes 1 to 3 in the analysis, and to reduce potential inaccurate locations, we excluded points that were indicative of transit speeds $>5 \mathrm{~km} \mathrm{~h}^{-1}$ (following standard filtering techniques, e.g. Luschi et al. 1998, James et al. 2005, Hawkes et al. 2007, Mansfield et al. 2009). Filtering removed $1.14 \%$ of the locations.

We excluded the first $10 \mathrm{~d}$ ( $3 \%$ of the total points) of tracking data from each turtle to avoid including immediate potential post-release behavior that may have been affected by the capture event. This resulted in a total of 26 turtles utilized in the present study (for summary information, refer to Table 1), as Turtle 79832 transmitted for only $3 \mathrm{~d}$. We do not draw conclusions in relation to the nature of transmission cessation or the effects of injury on tracked individuals in the present study. Of the total LC filtered positions for the remaining 26 turtles $(\mathrm{n}=3435$ good quality locations), net displacements between consecutive daily locations for each individual turtle were calculated using Hawth's Geospatial Analysis tools (www.spatialecology.com/htools) summing over the entire track length to obtain the minimum distance traveled by each turtle. We divided the distance between 2 observed locations separated by $>24 \mathrm{~h}$ by the number of missing days (James et al. 2005, Mansfield et al. 2009). Average travel rate $\left(\mathrm{km} \mathrm{h}^{-1}\right)$ for individual turtles were calculated using the ratio of net displacement between each consecutive location and the time elapsed between each location.

Seasons and bathymetric domains were defined as follows: summer (January to March), autumn (April to June), winter (July to September), spring (October to December), continental shelf (0 to $200 \mathrm{~m}$ ), continental shelf break ( $>200$ to $1000 \mathrm{~m}$ ), slope (>1000 to $3000 \mathrm{~m})$, and oceanic (>3000 m). Bathymetry data (1' latitude/longitude resolution) were obtained from the General Bathymetric Chart of the Oceans (GEBCO, British Oceanographic Data Centre, www. bodc.ac.uk). World exclusive economic zone (EEZ) boundaries were acquired from Flanders Marine Institute's Maritime Boundaries Geodatabase v.6.1 (VLIZ 2012). Weekly averaged SST and surface chl a data were obtained from STAT and used to obtain SST and chl $a$ values for each daily turtle location to characterize turtle and habitat associations. In STAT, SST data were derived from a weekly average of Advanced Very High Resolution Radiometer (AVHRR) sensors onboard NOAA satellites, and average weekly surface chl a was estimated from MODIS satellite sensors at $4 \mathrm{~km}$ resolution (Coyne \& Godley 2005).

\section{Vertical movements}

Maximum dive-depth histograms (described as the number of dives whose maximum depth was within the specified depth ranges or 'bins' for each $6 \mathrm{~h}$ period) were collected by each of the 5 functioning SPLASH satellite tags (see Table 1) and relayed through the ARGOS system. Turtles with tag numbers 79830,79831 , and 79835 were programmed with depth ranges distributed as follows: $0,10,20,50$, $100,150,200,300,400,500,600,700,800$, and $>800 \mathrm{~m}$. Turtles with tag numbers 79833 and 79834 were programmed as follows: $0,10,15,25,35,45,55$, 
$70,100,150,200,300,400$, and $>400 \mathrm{~m}$. To compare dive depth data among all diving turtles, we consolidated depth bins that ranged between 10 and $100 \mathrm{~m}$. Dive data were collected for every $6 \mathrm{~h}$ period throughout the day, starting at midnight GMT time. For the 5 turtles equipped with SPLASH tags, a total of 1798 dive depth histograms (6 h bins) were reported during the tracking duration.

\section{High-use areas}

To examine habitat use, the number of filtered daily locations was tallied within hexagonal area bins. In the present study and similar to grids used by James et al. (2005) and Mansfield et al. (2009), hexagonal area bins were chosen over square bins to more accurately capture the orthogonality of movement paths between adjacent cells. The diagonal and edge length of each hexagonal cell were $64.3 \mathrm{~km}$ and $32.2 \mathrm{~km}$, respectively, and each hexagonal cell had an area of $2686 \mathrm{~km}^{2}$ (which is greater than the estimated location error associated with the least precise position estimate; LC 1: 350 to $1000 \mathrm{~m}$ error) (CLS 2007, Mansfield et al. 2009). Each $1^{\circ}$ of latitude in the study region was represented by $\sim 1.5$ hexagons $(\sim 90 \mathrm{~km})$. For defining high-use areas, we created 50 and $75 \%$ utilization distribution (UD) contours of turtle tracking days using the Spatial Analyst extension of ArcGIS (ESRI), using a smoothing factor of $120 \mathrm{~km}$ and a grid size of $10 \mathrm{~km}$.

Independently of the high-use area analysis, we also simply classified turtles in regard to their distributions within bathymetric zones using a threshold of $\geq 75 \%$ of each turtle's daily locations as being contained within either the neritic/shelf-break region ( 0 to $1000 \mathrm{~m}$ ), the slope region (>1000 to $3000 \mathrm{~m}$ ), the oceanic region $(>3000 \mathrm{~m})$, or in mixed regions (turtles having $<75 \%$ of locations in any 1 region).

\section{Statistical analyses}

All track analyses were carried out in ArcMap 9.2 (ESRI) in a projected Universal Transverse Mercator $22 \mathrm{~S}$ coordinate system to avoid distortion associated with geographic coordinate systems. All statistical analyses were conducted in the program R v.2.9.2 (R Development Core Team 2009). We used 1-way analysis of variance (ANOVA) with a post-hoc Tukey test to test for seasonal differences in oceanographic conditions experienced by tracked turtles. Additionally, as travel rate data did not meet the assumption of normality, we used the Kruskal-Wallis test (Zar 1996) with a post-hoc Wilcoxon rank sum test to evaluate differences in median speed among seasonal groups as well as bathymetric zone turtle classification groupings. As the strength of inference on the importance of turtle size (CCL) for turtle behavior or habitat use was low due to small sample size and unequal size distribution of tracked turtles (see Table 1), we did not include CCL in statistical analyses. The statistical significance level for all analyses was set to $\alpha=0.05$. All descriptive statistics are presented as mean $\pm \mathrm{SD}$.

\section{RESULTS}

\section{Turtles}

The overall CCL was $61.8 \pm 6.9 \mathrm{~cm}$ (range: 49 to $83 \mathrm{~cm}, \mathrm{n}=27$, Table 1). All turtles were captured and released within Uruguayan or Brazilian EEZ over the continental shelf or slope $(\mathrm{n}=24$; approximately along $53^{\circ} \mathrm{W}$, in waters $>200 \mathrm{~m}$ in depth) or in international waters $(\mathrm{n}=3)$ (Table 1, Fig. 1).

\section{General movements}

The overall mean turtle tracking duration for the study period was $259 \pm 159$ d (range: 3 to $639 \mathrm{~d}$, $\mathrm{n}=$ 27 ), and the minimum distance from release location for all turtles transmitting $>10 \mathrm{~d}$ was $6050 \pm 3630 \mathrm{~km}$ (range: 153 to $14665 \mathrm{~km}, \mathrm{n}=26$ ) (Table 1). During the entire monitoring period, 5 turtles were tracked for $>1 \mathrm{yr}, 20$ were tracked for 100 to $365 \mathrm{~d}$, and 2 turtles were monitored for $<100 \mathrm{~d}$ before their transmissions ceased in March 2010. All turtle movements were contained within a relatively small region of the SWA, including part of the Uruguayan, Brazilian, and Argentinean EEZs and adjacent international waters. The movements spanned a minimum convex polygon area of $2244685 \mathrm{~km}^{2}$ (Fig. 1). Horizontal tracks were distributed between 25 and $45^{\circ} \mathrm{S}$ latitude and between 35 and $54^{\circ} \mathrm{W}$ longitude (Fig. 1). Of the turtles tracked, Turtle 79820 traveled the farthest north, reaching $25^{\circ} 49^{\prime} \mathrm{S}, 40^{\circ} 30^{\prime} \mathrm{W}$ in December 2008. Turtle 79821 traveled the farthest south, reaching $45^{\circ} 40^{\prime} \mathrm{S}$ and $50^{\circ} 58^{\prime} \mathrm{W}$ in October 2008. Two turtles (12096 and 79830) were classified as predominantly within the neritic/shelf-break region $(>75 \%$ of their movements), and both spent $>50 \%$ of their time within the $200 \mathrm{~m}$ isobath (Turtle 12096: $86 \%$, Turtle 79830: $56 \%$ ). The remaining turtles were classified 
Table 1. Summary table with information from 27 satellite tracked immature loggerhead turtles in the SW Atlantic Ocean between 2006 and 2010. Turtle 79832, indicated with an asterisk $\left(^{*}\right)$, transmitted for $<10 \mathrm{~d}$ and was excluded from all subsequent analysis. Dates given as mm/dd/yy. CCL: curved carapace length, Year: year of turtle release, BR: Brazil, UY: Uruguay, IW: international waters, ST: still transmitting as of 24 March 2010, NA: not available

\begin{tabular}{|c|c|c|c|c|c|c|c|c|c|c|c|}
\hline Year & PTT & $\begin{array}{c}\text { Type of } \\
\text { tag }\end{array}$ & $\begin{array}{l}\text { CCL } \\
(\mathrm{cm})\end{array}$ & $\begin{array}{c}\text { Deploy } \\
\text { date }\end{array}$ & $\begin{array}{l}\text { Release } \\
\text { location }\end{array}$ & $\begin{array}{l}\text { End } \\
\text { date }\end{array}$ & $\begin{array}{c}\text { Last } \\
\text { location }\end{array}$ & $\begin{array}{c}\text { Track } \\
\text { classi- } \\
\text { fication }\end{array}$ & $\begin{array}{l}\text { Tracking } \\
\text { duration } \\
\text { (d) }\end{array}$ & $\begin{array}{c}\text { Minimum } \\
\text { distance } \\
\text { traveled } \\
(\mathrm{km})\end{array}$ & $\begin{array}{l}\text { Average } \\
\text { daily rate } \\
\text { of travel } \\
\left(\mathrm{km} \mathrm{h}^{-1}\right)\end{array}$ \\
\hline \multirow[t]{2}{*}{2006} & 12499 & ST-20 & 62 & 07/01/06 & $\mathrm{BR}$ & 01/27/08 & IW & Oceanic & 575 & 14664.72 & 1.29 \\
\hline & 12580 & ST-20 & 63 & 07/06/06 & $\mathrm{BR}$ & $01 / 29 / 07$ & IW & Oceanic & 207 & 5164.07 & 1.23 \\
\hline \multirow[t]{7}{*}{2007} & 12415 & ST-20 & 62 & $04 / 24 / 07$ & $\mathrm{BR}$ & 03/16/08 & BR & Mixed & 327 & 6357.38 & 0.94 \\
\hline & 12690 & ST-20 & 61 & $04 / 29 / 07$ & $\mathrm{BR}$ & 03/07/08 & IW & Mixed & 313 & 5062.91 & 0.85 \\
\hline & 12682 & ST-20 & 63 & $05 / 31 / 07$ & $\mathrm{BR}$ & 05/18/09 & $\mathrm{BR}$ & Oceanic & 639 & 10013.04 & 0.92 \\
\hline & 12826 & ST-20 & 83 & 06/05/07 & $\mathrm{BR}$ & $11 / 15 / 07$ & BR & Mixed & 163 & 3248.54 & 1.11 \\
\hline & 12258 & ST-18 & 59 & 06/26/07 & IW & $07 / 25 / 07$ & IW & Oceanic & 29 & 153.47 & 0.46 \\
\hline & 12376 & ST-18 & 51.5 & 06/29/07 & IW & $10 / 12 / 08$ & IW & Oceanic & 471 & 7454.06 & 0.77 \\
\hline & 12372 & ST-18 & 73.5 & 09/16/07 & BR & 06/07/08 & $\mathrm{BR}$ & Mixed & 265 & 5602.97 & 0.93 \\
\hline \multirow[t]{12}{*}{2008} & 12284 & ST-18 & 72 & 06/27/08 & $\mathrm{BR}$ & $12 / 13 / 08$ & BR & Oceanic & 169 & 3569.42 & 1.15 \\
\hline & 12096 & ST-18 & 69 & 08/18/08 & IW & 05/18/09 & $\mathrm{BR}$ & Neritic & 273 & 3979.12 & 0.58 \\
\hline & 79820 & SPOT 5 & 60 & $04 / 02 / 08$ & UY & 01/29/09 & UY & Mixed & 305 & 7406.56 & 0.89 \\
\hline & 79821 & SPOT 5 & 56 & 04/03/08 & UY & 03/20/09 & IW & Oceanic & 351 & 13202.68 & 1.59 \\
\hline & 79822 & SPOT 5 & 63 & $04 / 02 / 08$ & UY & 06/02/09 & IW & Oceanic & 426 & 11444.75 & 1.11 \\
\hline & 79823 & SPOT 5 & 60 & 05/26/08 & UY & $11 / 01 / 09$ & $\mathrm{BR}$ & Mixed & 524 & 11063.76 & 0.95 \\
\hline & 79830 & SPLASH & 68 & 04/02/08 & UY & 09/20/08 & $\mathrm{BR}$ & Neritic & 174 & 3889.40 & 0.90 \\
\hline & 79831 & SPLASH & 56 & $04 / 05 / 08$ & UY & $11 / 06 / 08$ & IW & Mixed & 215 & 9832.29 & 1.89 \\
\hline & $79832^{*}$ & SPLASH & 49 & $05 / 26 / 08$ & UY & $05 / 28 / 08$ & UY & NA & 3 & 81.97 & 2.17 \\
\hline & 79833 & SPLASH & 64 & $05 / 26 / 08$ & UY & $11 / 03 / 08$ & IW & Oceanic & 161 & 3006.35 & 0.77 \\
\hline & 79834 & SPLASH & 64 & $05 / 26 / 08$ & UY & $10 / 18 / 08$ & IW & Oceanic & 145 & 4096.76 & 1.21 \\
\hline & 79835 & SPLASH & 63 & 03/30/08 & UY & $10 / 08 / 08$ & $\mathrm{BR}$ & Mixed & 192 & 5026.93 & 1.13 \\
\hline \multirow[t]{6}{*}{2009} & 95591 & SPOT 5 & 57 & $11 / 11 / 09$ & UY & $\mathrm{ST}$ & IW & Oceanic & 136 & 3648.10 & 1.08 \\
\hline & 95592 & SPOT 5 & 58 & $11 / 11 / 09$ & UY & ST & $\mathrm{BR}$ & Mixed & 135 & 3955.60 & 1.33 \\
\hline & 95593 & SPOT 5 & 59 & $11 / 11 / 09$ & UY & ST & IW & Oceanic & 135 & 4080.60 & 1.32 \\
\hline & 95594 & SPOT 5 & 55 & 08/26/09 & UY & $\mathrm{ST}$ & IW & Oceanic & 212 & 6928.19 & 1.34 \\
\hline & 95595 & SPOT 5 & 58 & 08/26/09 & UY & 03/10/09 & $\mathrm{BR}$ & Mixed & 196 & 3981.23 & 0.84 \\
\hline & 95596 & SPOT 5 & 62 & 08/25/09 & UY & $03 / 16 / 10$ & UY & Mixed & 202 & 6423.73 & 2.98 \\
\hline
\end{tabular}

as either primarily oceanic $(\mathrm{n}=13)$ or within the mixed group $(n=11)$. No turtles were classified into the slope group.

The mean rate of travel for all successfully tracked turtles was $1.13 \pm 0.86 \mathrm{~km} \mathrm{~h}^{-1}(\mathrm{n}=26$ turtles) and 1.04 $\pm 0.78 \mathrm{~km} \mathrm{~h}^{-1}(\mathrm{n}=24$ turtles$)$ when the 2 fastest turtles were excluded. Turtles 79831 and 95596 had considerably higher mean rates of travel than the other tracked turtles $(1.83 \pm 0.94$ and $1.75 \pm 1.07 \mathrm{~km}$ $\mathrm{h}^{-1}$, respectively). Approximately $55 \%$ of the recorded daily rates of travel were between 0 and 1.5 $\mathrm{km} \mathrm{h}^{-1}$. Mean rate of travel varied among turtles (Kruskal-Wallis, $\chi^{2}=462.04, \mathrm{df}=25, \mathrm{p}<0.0001$ ), and there were significant rate of travel differences among the bathymetric zone classification groups (Kruskal-Wallis, $\chi^{2}=61.08, \mathrm{df}=2, \mathrm{p}<0.0001$ ), specifically, between neritic/shelf-break vs. oceanic $(\mathrm{p}<$ $0.001)$ and neritic/shelf-break vs. mixed group $(\mathrm{p}<$ $0.0001)$. The rate of travel of neritic/shelf-break tur- tles was significantly slower $\left(0.77 \pm 0.63 \mathrm{~km} \mathrm{~h}^{-1}\right)$ than turtles in the other 2 categories (mixed group: $1.17 \pm$ $0.87 \mathrm{~km} \mathrm{~h}^{-1}$, oceanic group: $1.12 \pm 0.85 \mathrm{~km} \mathrm{~h}^{-1}$ ). No significant differences in travel rates were found between the oceanic vs. mixed group turtles $(p=$ $0.63)$.

\section{High-use areas}

Hexagonal binning of tracking data (Fig. 2) and kernel utilization distributions (50 and 75\%) (Fig. 3) indicated that the areas of highest use for the 26 tracked turtles were mainly concentrated over the continental shelf and slope within the northern portion of the Argentinean, Uruguayan, and southern portion of the Brazilian EEZs and in oceanic international waters between the Rio Grande Rise and the continental slope off of Brazil. Over the continental 


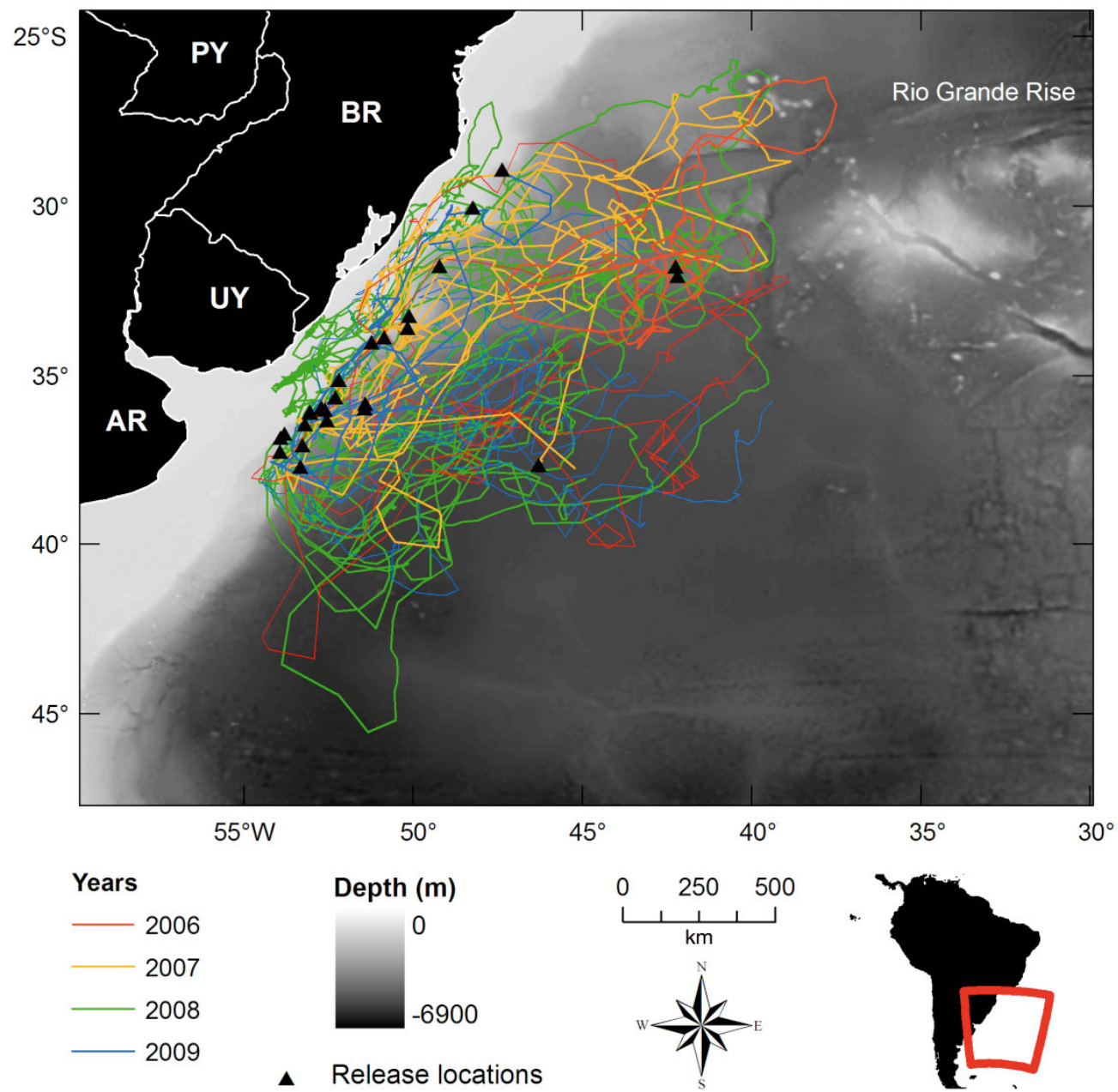

Fig. 1. Movement paths of 26 immature loggerheads in the SW Atlantic Ocean between 2006 and 2010. Release locations for each turtle indicated by black triangles. Minimum convex polygon indicates the total area $\left(\sim 2250000 \mathrm{~km}^{2}\right)$ utilized by all tracked turtles. PY: Paraguay, BR: Brazil, UY: Uruguay, AR: Argentina shelf in northern Uruguayan and southern Brazilian EEZ, 5 individual hexagonal bins contained between 25 and 36 turtle days, which reflect the cumulative use of 4 and 5 turtles each, $15 \%$ of all studied turtles (Fig. 2).

\section{Diving behavior}

On average, for the 5 SPLASH tagged turtles, 15\% percent of dives were to depths less than $10 \mathrm{~m}, 84 \%$ of dives were between 10 and $100 \mathrm{~m}$, and $1 \%$ of dives were to depths greater than $100 \mathrm{~m}$. Maximum dive depth ranges for each of the 5 turtles that collected dive data are reported in Table 2. Percentages of dives reaching each depth bin did not vary noticeably by season. The maximum dive depth range was achieved by Turtles 79830 and 79835 , which reached the 200 to $300 \mathrm{~m}$ bin in 2008. The neritic/shelf-break turtle, Turtle 79830, had dives that reached the 200 to
$300 \mathrm{~m}$ bin in regions where, according to bathymetric data, the water column was <200 m deep (Table 2). This indicates that this turtle may have been foraging close or at the seafloor in $\sim 200 \mathrm{~m}$ of water, but the discrepancy between the depth reached in dives and the bathymetry suggests a possible measurement error in either the turtle's exact location and/or bathymetric data. For the turtles classified into the mixed group (Turtles 79831 and 79835), maximum dive-depth bins reached in the 3 different bathymetric regions was 200 to $300 \mathrm{~m}$. Both oceanic turtles dove to depths greater than $70 \mathrm{~m}$ in the water column; Turtle 79833 reached a maximum depth bin range of 100 to $150 \mathrm{~m}$.

\section{Seasonality}

The quarterly latitude frequency plot (Fig. 4) illustrates seasonal variations in north to south turtle 


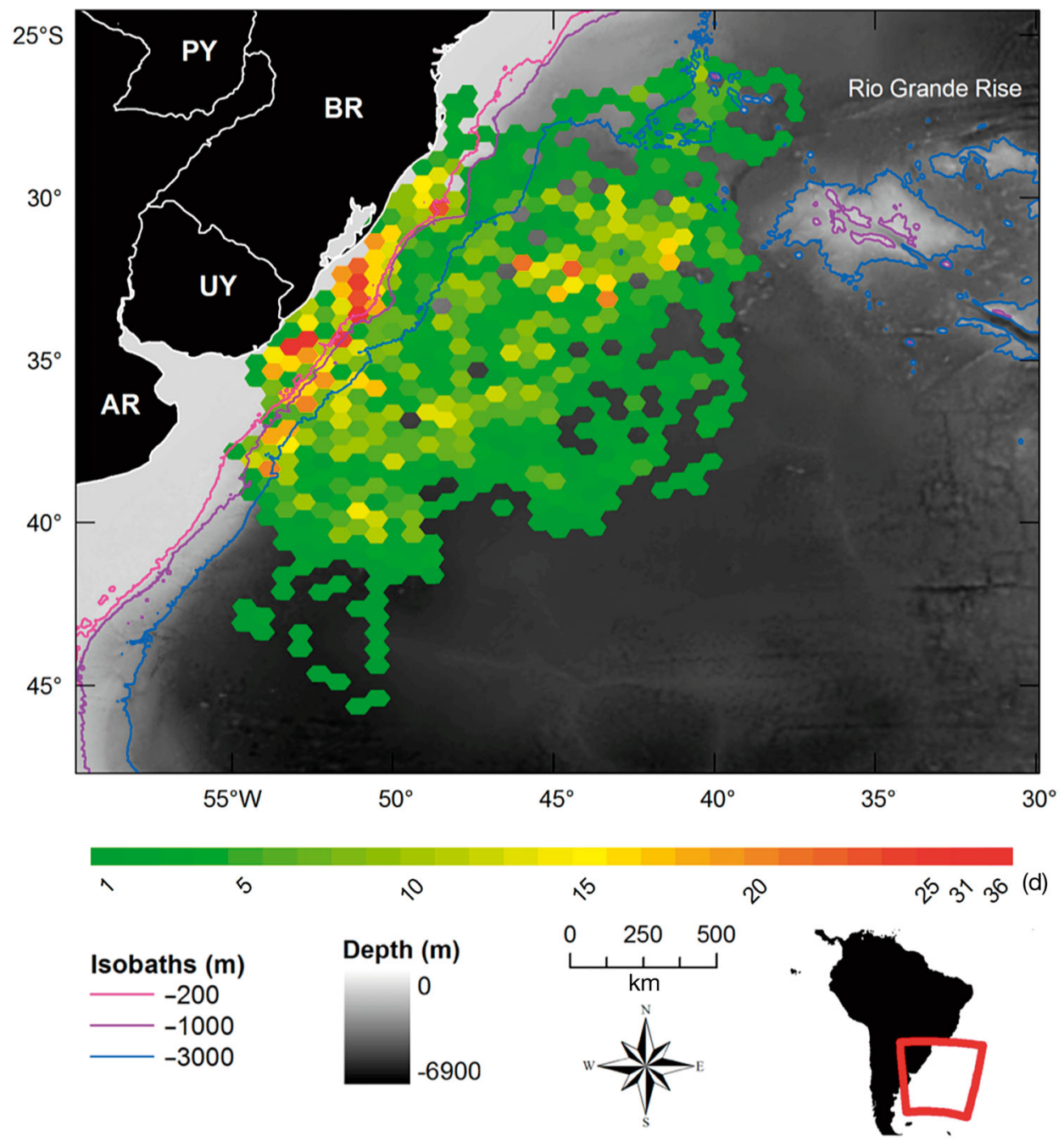

Fig. 2. Spatial use of 26 immature loggerheads tracked in the SW Atlantic between 2006 and 2010. Color denotes the number of days a turtle spent within each hexagonal bin with 200, 1000 , and $3000 \mathrm{~m}$ isobaths

movement in the SWA study region. There were significant differences in mean latitude between seasons (ANOVA, $\left.F_{3,58}=7.45, \mathrm{p}=0.0013\right)$, and a posthoc Tukey test showed that the mean latitude was significantly different between summer and winter, summer and spring, and spring and winter $(\mathrm{p}<$ 0.0001). During winter, turtles were distributed between 26 and $41^{\circ} \mathrm{S}$, and they spent a high percentage of their time between 31 and $32^{\circ} \mathrm{S}\left(32.4 \pm 3.1^{\circ} \mathrm{S}\right)$ (Fig. 4). During autumn, turtle movements ranged between 27 and $42^{\circ} \mathrm{S}$, occurring $55 \%$ of the time in latitudes between 34 and $38^{\circ} \mathrm{S}\left(34.7 \pm 3.1^{\circ} \mathrm{S}\right)$. In the spring, turtles moved between 26 and $46^{\circ} \mathrm{S}$, where $>75 \%$ of all locations were between 31 and $37^{\circ} \mathrm{S}$ $\left(33.2 \pm 3.36^{\circ} \mathrm{S}\right)$, and in summer, turtles moved between 30 and slightly more than $44^{\circ} \mathrm{S}$, spending $\sim 64 \%$ of their time between latitudes of 35 and $39^{\circ} \mathrm{S}$ $\left(36.1 \pm 2.6^{\circ} \mathrm{S}\right)$.
There were also differences in mean speed by season (Kruskal-Wallis, $\chi^{2}=122.14$, df $=3, \mathrm{p}<$ $0.0001)$, and pairwise comparisons indicated that summer rates of travel $\left(1.3 \pm 0.99 \mathrm{~km} \mathrm{~h}^{-1}\right)$ were not significantly different than those in autumn $(1.2 \pm$ $\left.0.77 \mathrm{~km} \mathrm{~h}^{-1}\right)(\mathrm{p}=0.97)$ but were significantly faster than those in winter $\left(0.9 \pm 0.72 \mathrm{~km} \mathrm{~h}^{-1}\right)(p=0.021)$ and those in spring $\left(1.16 \pm 0.88 \mathrm{~km} \mathrm{~h}^{-1}\right)(\mathrm{p}=$ 0.021 ). Autumn rates of travel were significantly faster than those in winter $(p<0.0001)$ and those in spring $(p=0.024)$. Winter rates of travel were significantly slower than those in spring $(\mathrm{p}<$ 0.0001).

The turtles' movements in relation to SST were also observed to vary between different seasons of the study years. The overall mean SST encountered by the tracked turtles was $20 \pm 2.3^{\circ} \mathrm{C}$ (range: 10.2 to $28.4^{\circ} \mathrm{C}$ ). More than $98 \%$ of the turtle tracks 


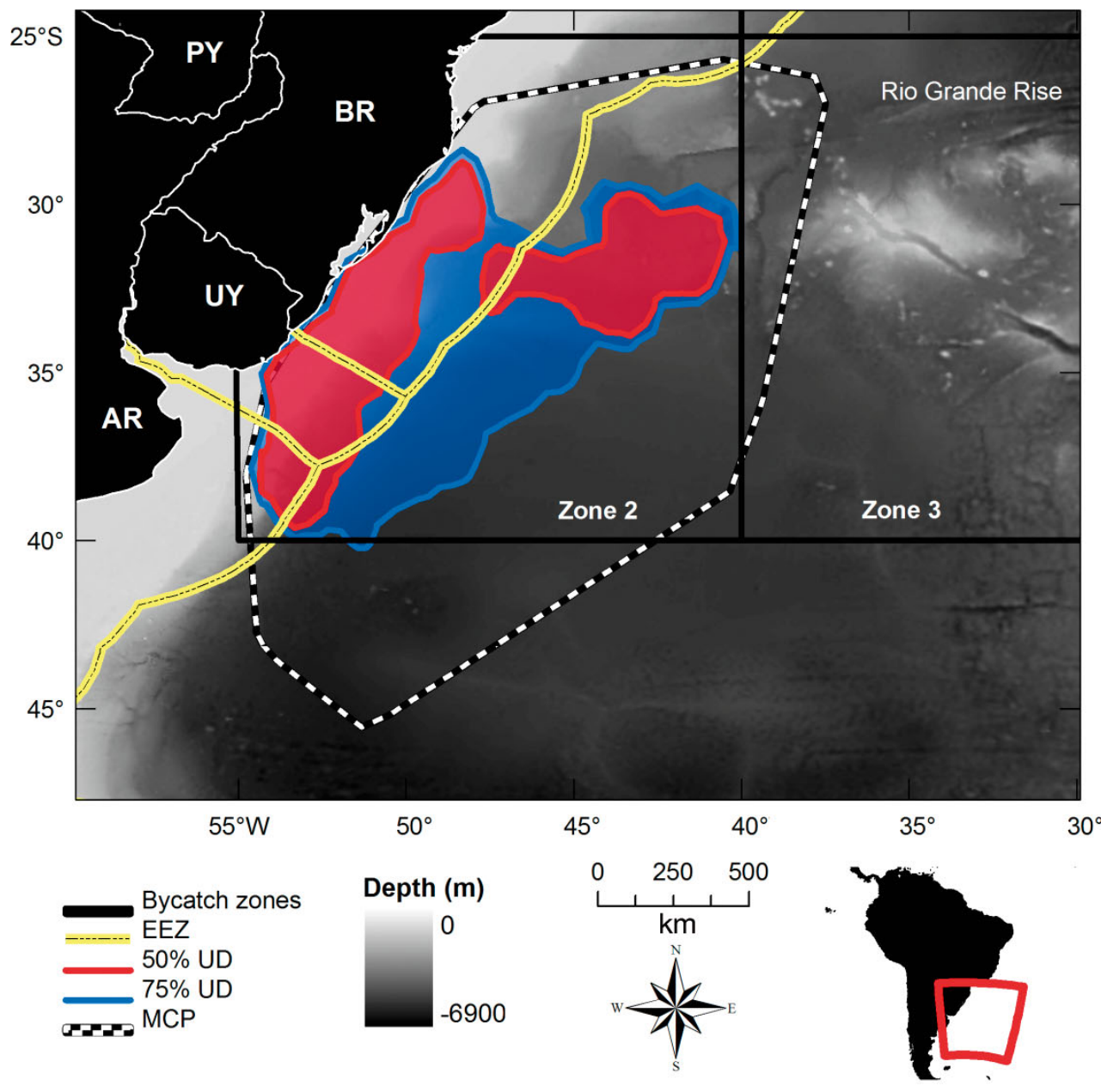

Fig. 3. High-use areas defined by 50 and $75 \%$ utilization distributions (UD) plotted with exclusive economic zones (EEZ) of adjacent countries, the minimum convex polygon $(\mathrm{MCP})$, and bycatch zones specified by Giffoni et al. (2008)

Table 2. Maximum dive-depth bin reached in different bathymetric regions by each turtle equipped with a SPLASH tag. ND: no data. Groupings refer to which bathymetric region the turtle spent the most time $(>75 \%$ of tracked days) over the tracking duration

\begin{tabular}{|lccccr|}
\hline \multirow{2}{*}{ PTT } & \multirow{2}{*}{ Grouping } & \multicolumn{5}{c|}{$\begin{array}{c}\text { Bathymetric regions }(\mathrm{m}) \\
\text { Break }\end{array}$} & $\begin{array}{c}\text { Shelf } \\
\text { She }\end{array}$ & $\begin{array}{c}\text { Oceanic } \\
(0-200)\end{array}$ & $(>200-1000)$ & $(>1000-3000)$ & $(>3000)$ \\
\hline 79830 & Neritic & $150-200$ & $200-300$ & $100-150$ & $200-300$ \\
79831 & Mixed & $100-150$ & $100-150$ & $100-150$ & $100-150$ \\
79833 & Oceanic & ND & ND & ND & $100-150$ \\
79834 & Oceanic & ND & ND & $25-35$ & $70-100$ \\
79835 & Mixed & $200-300$ & $200-300$ & $150-200$ & $100-150$ \\
\hline
\end{tabular}

(post-hoc Tukey test, p < 0.05). Turtles experienced cooler surface temperatures during the winter (mean $\left.\mathrm{SST}: 18 \pm 1.8^{\circ} \mathrm{C}\right)$ and spring $(19 \pm$ $\left.2^{\circ} \mathrm{C}\right)$ than during the summer $(22 \pm$ $\left.2{ }^{\circ} \mathrm{C}\right)$ and autumn $\left(20 \pm 2^{\circ} \mathrm{C}\right)$ seasons (Fig. 4).

There were no significant seasonal trends in relation to chl a (ANOVA, $\left.F_{3,58}=1.76, \mathrm{p}=0.18\right)$. Turtles showed an affinity for chl a density values between 0.1 and $1 \mathrm{mg} \mathrm{m}^{-3}(0.43 \pm$ $0.89 \mathrm{mg} \mathrm{m}^{-3}$ ). During the autumn, winter, spring, and summer seasons,

were in surface waters of temperatures greater than $15^{\circ} \mathrm{C}$. There were significant differences in mean SST between seasons (ANOVA, $F_{3,58}=$ 56.52, p < 0.001), and similar to latitude, mean SST differed significantly between summer and winter, summer and spring, and spring and winter seasons turtles spent $77.7,75.1,65.1$, and $67.8 \%$ of their time, respectively, in areas where surface chl a concentration ranged between 0.2 and $0.4 \mathrm{mg} \mathrm{m}^{-3}$. There was no evident seasonality in the turtle's use of different bathymetric regions (ANOVA, $F_{3,58}=$ 0.28, $\mathrm{p}=0.75$ ). 

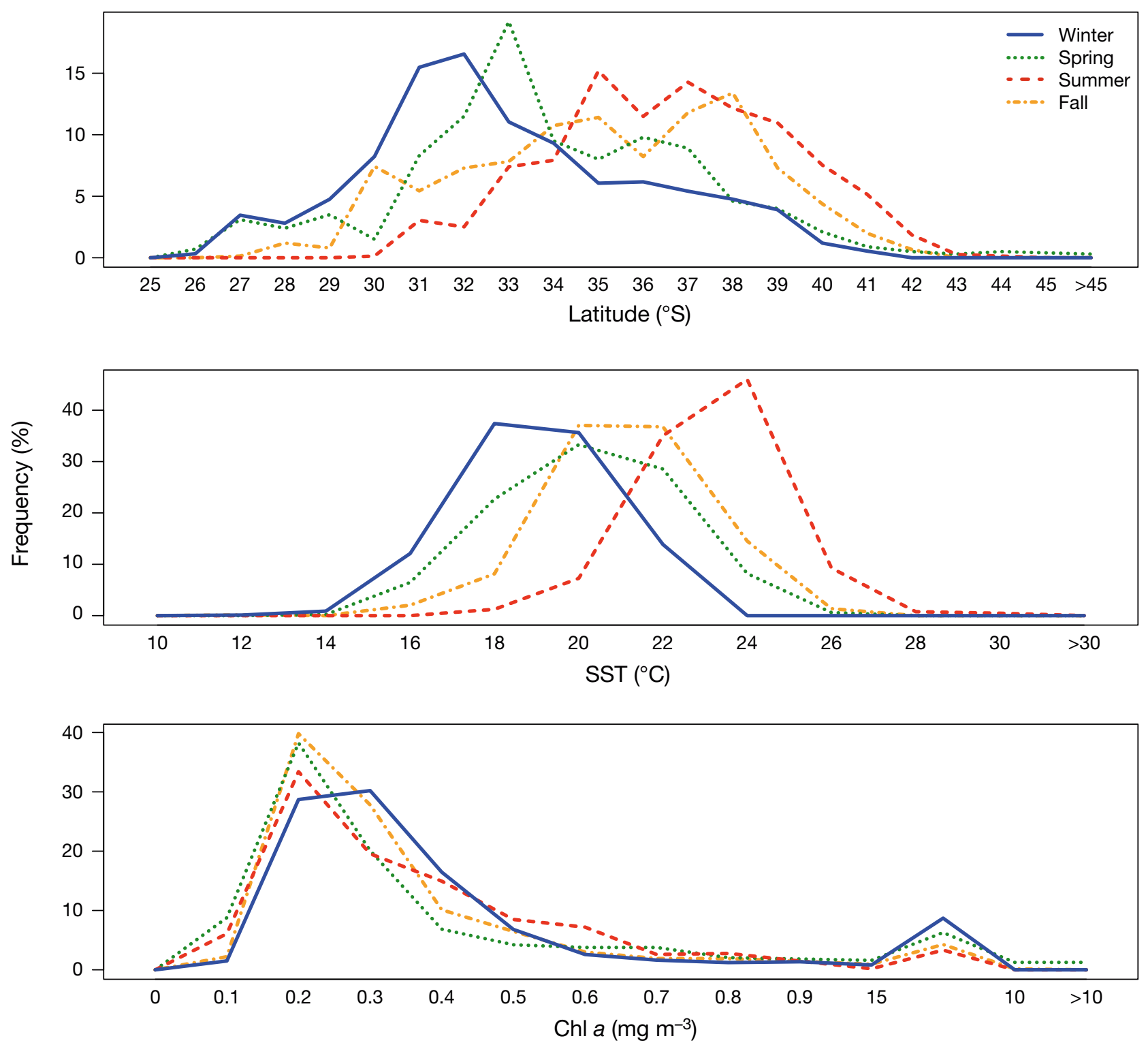

Fig. 4. Quarterly frequency distribution plots of (a) latitude, (b) sea surface temperature (SST) and (c) chl a. Seasons specified as follows: winter (July to September, $\mathrm{n}=924$ ), spring (October to December, $\mathrm{n}=1337$ ), summer (January to March, $\mathrm{n}=757$ ), autumn (April to June, $\mathrm{n}=754$ ). STAT-derived SST and chl a weekly averages identified for each first daily location point for all turtles

\section{DISCUSSION}

The present study is the first to present satellitetracking data of juvenile loggerheads in the SWA. A key result from the present study is the identification of the SWA as a juvenile loggerhead high-use area. All tracked turtles remained within a relatively small area $\left(\sim 2250000 \mathrm{~km}^{2}\right)$ during the entire $5 \mathrm{yr}$ of tracking; this is restricted compared to areas used by oceanic juveniles tracked in other major ocean basins (e.g. Kobayashi et al. 2008, Mansfield et al. 2009).
The minimum convex polygon represents only a portion of the known distribution of this species in the SWA, as tracked turtles did not move into areas such as the Rio Grande Rise and the Rio de la Plata estuary where juvenile loggerhead turtles are known to be incidentally captured by the Brazilian longline fleet (Sales et al. 2008) and Uruguayan and Argentinean coastal bottom trawl fisheries (P. Miller unpubl. data). The residence of turtles within the restricted area observed in our study is likely a result of the high prevalence of pelagic and benthic prey 
stemming from high primary production occurring along the Uruguayan, Argentinean, and Brazilian shelf and offshore regions. Similar residence patterns have been observed in the Mediterranean but mainly restricted to neritic areas (Casale et al. 2012).

The results indicate a strong seasonality in turtle movements in the SWA, a seasonality driven mainly by SST variability. In addition to seasonal shifts in latitude, turtles tracked in the present study also display seasonal patterns in their mean rates of travel that are consistent with the seasonal pattern in SST encountered by turtles in each season, where highest and lowest temperatures and speeds are in the summer and winter, respectively. The variability in temperatures in the SWA are evidenced by satellite images demonstrating that the warm Brazil current reaches its southernmost latitude during the austral summer (January, February, and March), whereas in the austral winter (June, July, and August), colder waters dominate as the Malvinas current reaches northernmost latitudes (Garzoli 1993). This seasonality in the turtle movements is similar that of to tracked loggerheads in the North Pacific (Polovina et al. 2004, Kobayashi et al. 2008), as well as that of juvenile loggerheads tracked in the North Atlantic (Mansfield et al. 2009) and along the Italian coast (Bentivegna 2002, Bentivegna et al. 2007). In contrast, juvenile loggerheads in the western Mediterranean (Algerian Basin) do not demonstrate seasonality in their movements, which Revelles et al. (2007) explain by the fact that the Algerian Basin is largely thermally homogenous. Other studies on adult loggerheads, as well as leatherback turtles, also indicate the presence of a seasonal north-south trend in migration patterns (Plotkin \& Spotila 2002, HopkinsMurphy et al. 2003, Hawkes et al. 2007, 2011). This seasonality is possibly driven by the species' thermal preference (Howell et al. 2010) or limit (McMahon \& Hays 2006). Our results are consistent with findings from other studies on juvenile loggerheads, as we also find that $\sim 98 \%$ of the turtle movements were in water temperatures greater than the $15^{\circ} \mathrm{C}$ isotherm.

Seasonality in movements may also be influenced by a combination of both thermal preference and prey availability in certain seasons. High prey availability is generally known to be associated with productive blooms during the spring and summer seasons corresponding with turtles being distributed more polewards, whereas during colder seasons, turtles will tend to be distributed more equatorward with warmer waters to rely more heavily upon prey concentrations at frontal regions/mesoscale eddies (Mansfield et al. 2009). Kobayashi et al. (2008) have found that latitudinal movements of loggerheads in the Pacific Ocean also correspond to variations in chl $a_{\text {; }}$ however, the tracked turtles in the present study do not seem to track chl a. It is important to note that there may also be lags between turtle movement and biological features, as turtles do not directly consume primary producers.

The SWA, characterized by the Brazil-Malvinas confluence, is a highly energetic and productive region (Chelton et al. 1990, Saraceno et al. 2005). From surface drifter data, mean surface currents in the study region range in mean speeds from 0.01 to $\sim 2.5 \mathrm{~km} \mathrm{~h}^{-1}$; however, this region (particularly around the Brazil-Malvinas Confluence) is highly variable (standard deviations as high as $1.44 \mathrm{~km} \mathrm{~h}^{-1}$ ), and maximum current speeds are reported to be up to $\sim 5 \mathrm{~km} \mathrm{~h}^{-1}$ (Vivier et al. 2000). Given this, turtle rates of travel in the present study area are well within those theoretically possible. A mean rate of travel of 1.04 or $1.1 \mathrm{~km} \mathrm{~h}^{-1}$ described for the turtles in the present study is comparable to mean rates of travel reported by Kobayashi et al. (2008) $(0.913 \mathrm{~km}$ $\left.\mathrm{h}^{-1}\right)$, Polovina et al. (2000) (1.08 $\left.\mathrm{km} \mathrm{h}^{-1}\right)$, Cejudo et al. (2006) $\left(\sim 1.3 \mathrm{~km} \mathrm{~h}^{-1}\right)$, and Nichols et al. (2000) $\left(1.05 \mathrm{~km} \mathrm{~h}^{-1}\right)$, among others. The tortuous tracks as well as the rates of travel exhibited by the SWA juvenile turtles could possibly be the result (to some degree) of passive transport by local currents in the region in addition to their own station-holding abilities, diving behavior, and directed active movements. While clearly demonstrated for leatherbacks (Gaspar et al. 2006), further research is necessary to differentiate between active and passive movement for loggerhead turtles of all life stages and in all ocean basins.

Tracking studies of juvenile loggerhead sea turtles have begun to describe their movements in relation to mesoscale features, such as fronts and eddies (Polovina et al. 2000, 2004, Bentivegna et al. 2007, Revelles et al. 2007, Kobayashi et al. 2008, Howell et al. 2010). The SWA is a region with high presence of warm and cold core eddies (Chelton et al. 1990) and a diversity of fronts (Acha et al. 2004), which are linked to the high primary productivity of the region (Saraceno et al. 2005) and have differing effects on fish biodiversity and abundance (Alemany et al. 2009). Although the present study does not address the fine-scale habitat associations of tracked turtles, further studies on these turtles could determine if they exhibit distinct scales of movement and whether those scales of movement are associated with mesoscale environmental features, such as eddies and fronts. Furthermore, with recent advances in 
detection and monitoring of remotely sensed oceanic frontal features (Belkin et al. 2009), a finer spatial and temporal scale identification of frontal regions may be possible, which may lead to a better understanding of the environments encountered by turtles (e.g. Kobayashi et al. 2011).

While there is recent evidence for a reversible ontogenetic shift in the North Atlantic population of loggerheads (McClellan \& Read 2007) and alternative foraging strategies in the North Pacific (Peckham et al. 2011), movement data from juvenile loggerheads in the SWA is suggestive of individuals in the 'juvenile transitional stage' (Bolten 2003). Bolten (2003) suggests that this transitional stage is likely to vary in duration and probably occurs in geographic regions where major currents near or enter into the neritic zone (Bolten 2003); the Brazil-Malvinas confluence is such a region. Most of the turtles tracked in the present study (15 individuals of 26 total) remained largely in the oceanic region (depths $>200 \mathrm{~m}$ ) for the entire tracking duration; however, 8 turtles moved from oceanic regions to neritic regions (<200 m depth) and remained in neritic regions until tracking cessation. Moreover, 2 turtles moved from oceanic regions to neritic regions and then back out to depths >200 m. Interestingly, 1 turtle (79823) moved from the oceanic to neritic, back out to the oceanic, and then back in to the neritic, spending multiple months in each habitat. The mean CCL for the tracked turtles in the present study is $\sim 61 \mathrm{~cm}$, which is larger than that reported for the transitional stage in other regions, e.g. $\sim 53 \mathrm{~cm}$ CCL reported by Tiwari et al. (2002) off the coast of Morocco; however, it falls within the overlapping neritic and oceanic turtle sizes (from 45 to $68 \mathrm{~cm}$ ) reported by Bolten (2003). In comparison, for immature loggerheads tracked in the NW Atlantic, it was found that those individuals that exhibited a preference for neritic habitats were not significantly larger than those that spent more time in the oceanic habitat (Mansfield et al. 2009). Regardless, our data are consistent with the hypothesis that immature loggerheads in the SWA do not recruit to the benthic phase in one step from a strict oceanic pelagic phase.

Further support for the 'transitional stage' hypothesis is given by the diving behavior presented in the present study as well as the diets of stranded loggerheads along the coast of Uruguay. Results from the present study demonstrate that 1 individual actively dove to depths close to the seafloor in regions within the $200 \mathrm{~m}$ isobath. Although this is not conclusive evidence of bottom feeding, it does suggest at least exploratory and possibly foraging dives.
Evidence also suggests that juveniles in this region may be foraging on the seafloor in neritic regions, based on a diet study of stranded juvenile loggerheads (Martinez-Souza 2009) along the Uruguayan coastline, where items such as crustaceans (Libinia spinosa and Dardanus arrosor insignis) and mollusks (Buccinanops cochlidium and Pachycymbiola brasiliana) were found in turtle stomachs. While we were not able to compare the sizes of turtles that spent a significant amount of time on the continental shelf to those tracked primarily in deeper depths in the present study (due to the small sample size), it is possible that larger juveniles in this region may display more dives to bottom depths than smaller individuals. Further investigation into the variation in diving patterns of juvenile loggerheads present in the SWA neritic region will help to further elucidate this facultative habitat shift.

A large proportion of the turtle movements presented in the present study fall within a high juvenile loggerhead turtle bycatch zone as identified by Giffoni et al. (2008) (Zone 2, from latitudes 25 to $39^{\circ} \mathrm{S}$ ) and by Sales et al. 2008 (Zone 3). Both the $50 \%$ and $75 \%$ utilization distributions are almost entirely contained within Zone 2 (Fig. 3). According to Giffoni et al. (2008), between January 2005 and July 2007, Zone 2 had the highest loggerhead catch-per-unit-offishing-effort (CPUE, number of turtles caught) values (0.939 turtles per 1000 hooks) and $78 \%(\mathrm{n}=1532$ turtles) of the total observed loggerhead captures for both the Brazilian and Uruguayan pelagic longline fleets. Similarly, Sales et al. (2008) also reported high CPUE values (up to 2.17 turtles per 1000 hooks) in this region using Brazilian pelagic longline data from 2003 to 2005. Additionally, bycatch data from Uruguayan and Brazilian pelagic longline fisheries operating in the SWA (Domingo et al. 2006, Giffoni et al. 2008, Sales et al. 2008) indicate that juvenile loggerheads are also distributed in oceanic waters to the north of the region that was utilized by tracked turtles in the present study. Associations between turtle bycatch positions, tracking locations, and physical and biological oceanographic features may lead to a more complete understanding of the possible environmental indicators for turtle interactions with pelagic longline sets (similar to that of the Hawaiibased pelagic longline Turtlewatch program) (Howell et al. 2008), which in turn may allow for more efficient future management.

The results of the present study clearly define the waters off southern Brazil and Uruguay as the first identified juvenile loggerhead developmental highuse area in the South Atlantic; however, much still 
remains to be understood about their environmental niche and vulnerability to anthropogenic threats in the region. We suggest that further research in this geographic region is needed to provide a more comprehensive view of the ecology of juvenile loggerheads in the SWA. For example, additional satellite telemetry studies and subsequent analysis of the horizontal and vertical behavior of juvenile-stage loggerheads along the SWA continental shelf will lend further insight into the prevalence of the 'transitional stage' or presence of the ontogenetic shift (be it reversible or discrete) as well as their 3-dimensional behavior in relation to regionally operating fisheries (Howell et al. 2010).

Recent research has also indicated the SWA to be an important area for other species of sea turtles (e.g. Lopez-Mendilaharsu et al. 2009) as well as seabirds (e.g. Jiménez et al. 2011), marine mammals (e.g. Passadore et al. 2013), and sharks (e.g. Hazin et al. 2008), which is likely due to the region's unique physiographic (i.e. extensive Patagonian shelf and steep slope) features and oceanographic conditions (i.e. Brazil-Malvinas Confluence). As the issue of bycatch is a regionally understood issue in pelagic longline fisheries as well as in other commercial and artisanal fisheries along the coasts of Uruguay, Brazil, and Argentina, further collaborative research with the fishing sector is required to quantify the proportion of overlap of fisheries with independent data on the distributions of sea turtles and other marine mega-vertebrates in the region. Fortunately, bycatch monitoring and mitigation has been operating at a high level for more than a decade due to the efforts of multiple regional fisheries management organizations since the late 1990s (Domingo et al. 2006), and researchers have performed pertinent research aiming to understand the spatio-temporal patterns in bycatch (Giffoni et al. 2008, Pons et al. 2010), the efficacy of mitigation measures (i.e. circle hooks; see Sales et al. 2008, Domingo et al. 2012), and the general ecological patterns of different life stages (e.g. Marcovaldi et al. 2010, González Carman et al. 2012) in the region.

Acknowledgements. Special thanks to Uruguay's and Brazil's scientific observers: S. Jimenez, M. Abreu, A. Loureiro, and F. Fiedler for deploying satellite transmitters and providing accompanying information on the bycatch turtles, as well as the skippers and crew of fishing vessels where turtles were captured and equipped with transmitters. We also thank M. Coyne and acknowledge the use of the Satellite Tracking and Analysis Tool (http://seaturtle.org). Funding for satellite transmitters and ARGOS satellite time was made available for this project by NOAA National Marine Fish- eries Service, Pacific Island Fisheries Science Center. The authors also thank T. Todd Jones, K. Bigelow, and 4 anonymous reviewers for helpful comments that improved the manuscript greatly. CICMAR is a non-profit Uruguayan NGO created in 2009 to further scientific investigation and management of regional flora and fauna. DINARA (Dirección Nacional de Recursos Aquáticos) is the entity responsible for the regulation and control of fishing in Uruguay. Projeto TAMAR is a conservation program of the Brazilian Ministry of the Environment, affiliated with ICMBio, comanaged by Fundação Pró-TAMAR, and officially sponsored by Petrobras.

\section{LITERATURE CITED}

Acha EM, Mianzan HW, Guerrero RA, Favero M, Bava J (2004) Marine fronts at the continental shelves of austral South America: physical and ecological processes. J Mar Syst 44:83-105

Alemany D, Acha EM, Iribarne O (2009) The relationship between marine fronts and fish diversity in the Patagonian Shelf Large Marine Ecosystem. J Biogeogr 36: 2111-2124

Alfaro-Shigueto J, Mangel JC, Bernedo F, Dutton PH, Seminoff JA, Godley BJ (2011) Small-scale fisheries of Peru: a major sink for marine turtles in the Pacific. J Appl Ecol 48:1432-1440

Belkin IM, Cornillon PC, Sherman K (2009) Fronts in Large Marine Ecosystems. Prog Oceanogr 81:223-236

Bentivegna F (2002) Intra-Mediterranean migrations of loggerhead sea turtles (Caretta caretta) monitored by satellite telemetry. Mar Biol 141:795-800

Bentivegna F, Valentino F, Falco P, Zambianchi E, Hochscheid S (2007) The relationship between loggerhead turtle (Caretta caretta) movement patterns and Mediterranean currents. Mar Biol 151:1605-1614

> Bjorndal KA, Bolten AB, Martins HR (2000) Somatic growth model of juvenile loggerhead sea turtles Caretta caretta: duration of pelagic stage. Mar Ecol Prog Ser 202:265-272

Bolten AB (1999) Techniques for measuring sea turtles. In: Eckert KL, Bjorndal KA, Abreu-Grobois FA, Donnelly M (eds) Research and management techniques for the conservation of sea turtles. SSC/IUCN Marine Turtle Specialist Group, p 110-115

Bolten AB (2003) Active swimmers - passive drifters: the oceanic juvenile stage of loggerheads in the Atlantic system. In: Bolten AB, Witherington BE (eds) Loggerhead sea turtles. Smithsonian Institution Press, Washington, DC, p 63-78

Cardona L, Revelles M, Carreras C, San Felix M, Gazo M, Aguilar A (2005) Western Mediterranean immature loggerhead turtles: habitat use in spring and summer assessed through satellite tracking and aerial surveys. Mar Biol 147:583-591

> Cardona L, Revelles M, Parga ML, Tomás J and others (2009) Habitat use by loggerhead sea turtles Caretta caretta off the coast of eastern Spain results in a high vulnerability to neritic fishing gear. Mar Biol 156:2621-2630

> Casale P, Broderick AC, Freggi D, Mencacci R, Fuller WJ, Godley BJ, Luschi P (2012) Long-term residence of juvenile loggerhead turtles to foraging grounds: a potential conservation hotspot in the Mediterranean. Aquatic Conserv 22:144-154

Cejudo D, Varo-Cruz N, Liria A, Castillo JJ, Bellido JJ, 
López-Jurado L (2006) Transatlantic migration of juvenile loggerhead turtles (Caretta caretta L.) from the Strait of Gibraltar. Mar Turtle Newsl 114:9-11

Chelton DB, Schlax MG, Witter DL, Richman JG (1990) Geosat altimeter observations of the surface circulation of the Southern Ocean. J Geophys Res 95:17877-17903

CLS (2007) ARGOS user's manual: worldwide tracking and environmental monitoring by satellite. 14 October 2008 update. Argos/CLS, Toulouse, available at www.argossystem.org/manual

Coyne MS, Godley BJ (2005) Satellite Tracking and Analysis Tool (STAT): an integrated system for archiving, analyzing and mapping animal tracking data. Mar Ecol Prog Ser 301:1-7

> Crouse DT, Crowder LB, Caswell H (1987) A stage-based population model for loggerhead sea turtles and implications for conservation. Ecology 68:1412-1423

> De Solla SR, Bonduriansky R, Brooks RJ (1999) Eliminating autocorrelation reduces biological relevance of home range estimates. J Anim Ecol 68:221-234

Dodd CK (1988) Synopsis of the biological data on the loggerhead sea turtle Caretta caretta (Linnaeus 1758): biological report. US Fish Wildl Serv, Washington, DC, p 1-110

Dodd CK, Byles R (2003) Post-nesting movements and behavior of loggerhead sea turtles (Caretta caretta) departing from East-Central Florida nesting beaches. Chelonian Conserv Biol 4:530-536

Domingo A, Bugoni L, Prosdocimi L, Miller P and others (2006) The impact generated by fisheries on sea turtles in the Southwestern Atlantic. WWF Marine Program for Latin America and the Caribbean, San José

> Domingo A, Pons M, Jiménez S, Miller P, Barceló C, Swimmer Y (2012) Circle hook performance in the Uruguayan pelagic longline fishery. Bull Mar Sci 88:499-511

Frieberg MA (1945) Observaciones sobre las tortugas de mar que se encuentran frente a las costas Argentianas. Physis 20:50-53

Garzoli SL (1993) Geostrophic velocity and transport variability in the Brazil-Malvinas Confluence. Deep-Sea Res I 40:1379-1403

Gaspar P, Georges JY, Fossette S, Lenoble A, Ferraroli S, Le Maho Y (2006) Marine animal behaviour: neglecting ocean currents can lead us up the wrong track. Proc Biol Sci 273:2697-2702

Giffoni B, Domingo A, Sales G, Niemeyer-Fiedler F, Miller P (2008) Iteracción de tortugas marinas (Caretta caretta y Dermochelys coriacea) con la pesca de palangre pelágico en el Atlántico Sudoccidental: una perspectiva regional para la conservación. Collect Vol Sci Pap-Int Comm Conserv Atl Tunas 62:1861-1870

Godley B, Blumenthal JM, Broderick AC, Coyne MS, Godfrey MH, Hawkes LA, Witt MJ (2008) Satellite tracking of sea turtles: Where have we been and where do we go next? Endang Species Res 4:3-22

González Carman V, Falabella V, Maxwell S, Albareda D, Campagna C, Mianzan H (2012) Revisiting the ontogenetic shift paradigm: the case of juvenile green turtles in the SW Atlantic. J Exp Mar Biol Ecol 440:141-148

> Hart KM, Hyrenbach K (2009) Satellite telemetry of marine megavertebrates: the coming of age of an experimental science. Endang Species Res 10:9-20

> Hatase H, Takai N, Matsuzawa Y, Sakamoto W and others (2002) Size-related differences in feeding habitat use of female adult loggerhead turtles Caretta caretta around
Japan determined by stable isotope analyses and satellite telemetry. Mar Ecol Prog Ser 233:273-281

> Hatase H, Omuta K, Tsukamoto K (2007) Bottom or midwater: alternative foraging behaviours in adult female loggerhead sea turtles. J Zool (Lond) 273:46-55

Hatase H, Omuta K, Tsukamoto K (2010) Oceanic residents, neritic migrants: a possible mechanism underlying foraging dichotomy in adult female loggerhead turtles (Caretta caretta). Mar Biol 157:1337-1342

> Hawkes LA, Broderick AC, Coyne MS, Godfrey MH and others (2006) Phenotypically linked dichotomy in sea turtle foraging requires multiple conservation approaches. Curr Biol 16:990-995

> Hawkes LA, Broderick AC, Coyne MS, Godfrey MH, Godley BJ (2007) Only some like it hot-quantifying the environmental niche of the loggerhead sea turtles. Divers Distrib 13:447-457

Hawkes LA, Witt MJ, Broderick AC, Coker JW and others (2011) Home on the range: spatial ecology of loggerhead turtles in Atlantic waters of the USA. Divers Distrib 17: 624-640

Hazin F, Broadhurst M, Amorin A, Arfelli C, Domingo A (2008) Catches of pelagic sharks by subsurface longline fisheries in the South Atlantic Ocean: a review of available data with emphasis on Uruguay and Brazil. In: Camhi MD, Pikitch EK, Babcock EA (eds) Sharks of the open ocean. Blackwell Scientific, New York, NY

> Heppell SS (1998) Application of life-history theory and population model analysis to turtle conservation. Copeia 1998:367-375

Heppell SS, Heppell SA, Read AJ, Crowder LB (2005) Effects of fishing on long lived marine organisms. In: Norse E, Crowder L (eds) Marine conservation biology: the science of maintaining the sea's biodiversity. Island Press, Washington, DC, p 211-231

Hopkins-Murphy SR, Owens DW, Murphy TM (2003) Ecology of immature loggerheads on foraging grounds and adults in internesting habitat in the eastern United States. In: Bolten AB, Witherington BE (eds) Loggerhead sea turtles. Smithsonian Institution Press, Washington, DC, p 79-92

Howell EA, Kobayashi DR, Parker DM, Balazs GH, Polovina JJ (2008) TurtleWatch: a tool to aid in the bycatch reduction of loggerhead turtles Caretta caretta in the Hawaiibased pelagic longline fishery. Endang Species Res 5: 267-278

Howell E, Dutton P, Polovina JJ, Bailey H, Parker DM, Balazs GH (2010) Oceanographic influences on the dive behavior of juvenile loggerhead turtles (Caretta caretta) in the North Pacific Ocean. Mar Biol 157:1011-1026

IUCN (2012) IUCN Red List of Threatened Species, Vers 2012.2. www.iucnredlist.org

James MC, Ottensmeyer CA, Myers RA (2005) Identification of high-use habitat and threats to leatherback sea turtles in northern waters: new directions for conservation. Ecol Lett 8:195-201

Jiménez S, Domingo A, Brazeiro A (2009) Seabird bycatch in the Southwest Atlantic: interaction with the Uruguayan pelagic longline fishery. Polar Biol 32:187-196

Jiménez S, Domingo A, Abreu M, Brazeiro A (2011) Structure of the seabird assemblage associated with pelagic longline vessels in the southwestern Atlantic: implications for bycatch. Endang Species Res 15:241-254

Kobayashi DR, Polovina JJ, Parker DM, Kamezaki N and others (2008) Pelagic habitat characterization of logger- 
head sea turtles, Caretta caretta, in the North Pacific Ocean (1997-2006): insights from satellite tag tracking and remotely sensed data. J Exp Mar Biol Ecol 356: 96-114

Kobayashi DR, Cheng IJ, Parker DM, Polovina JJ, Kamezaki N, Balazs GH (2011) Loggerhead turtle (Caretta caretta) movement off the coast of Taiwan: characterization of a hotspot in the East China Sea and investigation of mesoscale eddies. ICES J Mar Sci 68:707-718

Laporta M, Lopez G (2003) Loggerhead sea turtle tagged in Brazil caught by a trawler in waters of the common Argentinian-Uruguayan fishing area. Mar Turtle Newsl 102:14

Lewison RL, Crowder LB (2007) Putting longline bycatch of sea turtles into perspective. Conserv Biol 21:79-86

Lopez-Mendilaharsu M, Rocha CFD, Miller P, Domingo A, Prosdocimi L (2009) Insights on leatherback turtle movements and high use areas in the Southwest Atlantic Ocean. J Exp Mar Biol Ecol 378:31-39

Luschi P, Hays GC, Del Seppia C, Marsh R, Papi F (1998) The navigational feats of green sea turtles migrating from Ascension Island investigated by satellite telemetry. Proc R Soc Lond B 265:2279-2284

Mansfield K, Saba V, Keinath JA, Musick JA (2009) Satellite tracking reveals a dichotomy in migration strategies among juvenile loggerhead turtles in the Northwest Atlantic. Mar Biol 156:2555-2570

> Marcovaldi M, Chaloupka M (2007) Conservation status of the loggerhead sea turtle in Brazil: an encouraging outlook. Endang Species Res 3:133-143

- Marcovaldi MÂ, Marcovaldi GG (1999) Marine turtles of Brazil: the history and structure of Projeto TAMARIBAMA. Biol Conserv 91:35-41

Marcovaldi MA, Silva ACCD, Gallo BMG, Baptistotte C and others (2000) Recaptures of tagged turtles from nesting and feeding grounds protected by Projeto TAMARIBAMA, Brasil. In: Kalb HJ, Wibbels T (eds) Proc 19th Annu Symp Sea Turtle Biol Conser, 2-6 March 1999, South Padre Island, TX, USA. NOAA Tech Memo 443: 164-166

> Marcovaldi M, Lopez GG, Soares LS, Lima EHSM, Thomé JCA, Almeida AP (2010) Satellite-tracking of female loggerhead turtles highlights fidelity behavior in northeastern Brazil. Endang Species Res 12:263-272

Martinez-Souza G (2009) Ecologia alimentar da tartaruga marinha cabeçuda (Caretta caretta) no oceano Atlantico sul Ocidental, Uruguai. MS thesis. Universidade Federal do Rio Grande, Rio Grande do Sul, Brazil

McClellan CM, Read AJ (2007) Complexity and variation in loggerhead sea turtle life history. Biol Lett 3:592-594

> McClellan CM, Braun-McNeill J, Avens L, Wallace BP, Read AJ (2010) Stable isotopes confirm a foraging dichotomy in juvenile loggerhead sea turtles. J Exp Mar Biol Ecol 387:44-51

McMahon C, Hays G (2006) Thermal niche, large-scale movements and implications of climate change for a critically endangered marine vertebrate. Glob Change Biol 12:1330-1338

Mora O, Domingo A (2006) Informe sobre el Programa de Observadores a bordo de la flota atunera uruguaya (1998-2004). Collect Vol Sci Pap ICCAT 59:599-607

Morreale SJ, Standora EA (1998) Early life stage ecology of sea turtles in northeastern US waters. NOAA Tech Memo NMFS-SEFSC 413:1-49

Murphy RC (1914) Thalassochelys caretta in the South
Atlantic. Copeia 2:4

Musick J, Limpus CJ (1997) Habitat utilization and migration in juvenile sea turtles. In: Lutz P, Musick JA (eds) Biology of sea turtles. CRC Press, Boca Raton, FL, p 137-163

Nichols WJ, Resendiz A, Seminoff JA, Resendiz B (2000) Transpacific migration of a loggerhead turtle monitored by satellite telemetry. Bull Mar Sci 67:937-947

Passadore C, Domingo A, Szephegyi M, Secchi ER (2013) Influence of environmental and longline fishing operational variables on the presence of killer whales (Orcinus orca) in south-western Atlantic. J Mar Biol Assoc UK CJO2012 (in press) doi:10.1017/S002531541200166X

Peckham SH, Maldonado-Diaz D, Walli A, Ruiz G, Crowder LB, Nichols WJ (2007) Small-scale fisheries bycatch jeopardizes endangered Pacific loggerhead turtles. PLoS ONE 2:e1041

> Peckham SH, Maldonado-Diaz D, Tremblay Y, Ochoa R and others (2011) Demographic implications of alternative foraging strategies in juvenile loggerhead turtles Caretta caretta of the North Pacific Ocean. Mar Ecol Prog Ser 425:269-280

> Plotkin PT, Spotila JR (2002) Post-nesting migrations of loggerhead turtles Caretta caretta from Georgia, USA: conservation implications for a genetically distinct subpopulation. Oryx 36:396-399

> Polovina JJ, Kobayashi DR, Parker DM, Seki MP, Balazs GH (2000) Turtles on the edge: movement of loggerhead turtles (Caretta caretta) along oceanic fronts, spanning longline fishing grounds in the central North Pacific, 19971998. Fish Oceanogr 9:71-82

Polovina JJ, Balazs GH, Howell EA, Parker DM, Seki MP, Dutton PH (2004) Forage and migration habitat of loggerhead (Caretta caretta) and olive ridley (Lepidochelys olivacea) sea turtles in the central North Pacific Ocean. Fish Oceanogr 13:36-51

Polovina JJ, Uchida I, Balazs G, Howell EA, Parker D, Dutton P (2006) The Kuroshio Extension Bifurcation Region: a pelagic hotspot for juvenile loggerhead sea turtles. Deep-Sea Res II 53:326-339

> Pons M, Domingo A, Sales G, Fiedler FN, Miller P, Giffoni B, Ortiz M (2010) Standardization of CPUE of loggerhead sea turtle (Caretta caretta) caught by pelagic longliners in the Southwestern Atlantic Ocean. Aquat Living Resour 23:65-75

R Development Core Team (2009) R: a language and environment for statistical computing. $\mathrm{R}$ Foundation for Statistical Computing, Vienna

Rees AF, Saady SA, Broderick AC, Coyne MS, Papathanasopoulou N, Godley BJ (2010) Behavioural polymorphism in one of the world's largest populations of loggerhead sea turtles Caretta caretta. Mar Ecol Prog Ser 418: 201-212

Revelles M, Isern-Fontanet J, Cardona L, San Félix M, Carreras C, Aguilar A (2007) Mesoscale eddies, surface circulation and the scale of habitat selection by immature loggerhead sea turtles. J Exp Mar Biol Ecol 347:41-57

Sales G, Giffoni BB, Barata PCR (2008) Incidental catch of sea turtles by the Brazilian pelagic longline fishery. J Mar Biol Assoc UK 88:853-864

> Sales G, Giffoni BB, Fiedler FN, Azevedo VG, Kotas JE, Swimmer Y, Bugoni L (2010) Circle hook effectiveness for the mitigation of sea turtle bycatch and capture of target species in a Brazilian pelagic longline fishery. Aquat Conserv 20:428-436 
Saraceno M, Provost C, Piola AR (2005) On the relationship of satellite retrieved surface temperature fronts and chlorophyll $a$ in the Western South Atlantic. J Geophys Res 110:C11016, doi:10.1029/2004JC002736

Tiwari M, Bjorndal KA, Bolten A, Moumi A (2002) Morocco and Western Sahara: sites of an early neritic stage in the life history of loggerheads. In: Moiser A, Folley A, Brost B (eds) Proc 20th Annu Symp on sea turtle biology and conservation. NOAA Tech Memo NMFS-SEFSC 477:9

> Vigan X, Provost C, Podesta G (2000) Sea surface velocities from sea surface temperature image sequences: 2 . Application to the Brazil-Malvinas Confluence area. J Geophys Res 105(C8):19515-19534, doi:10.1029/2000JC

Editorial responsibility: Rory Wilson,

Swansea, UK
900028

VLIZ (2012) Maritime Boundaries Geodatabase, v6.1, available at www.vliz.be/vmdcdata/marbound

> Wallace BP, DiMatteo AD, Hurley BJ, Finkbeiner EM and others (2010) Regional management units for marine turtles: a novel framework for prioritizing conservation and research across multiple scales. PLoS ONE 5:e15465

Witt MJ, Akesson S, Broderick AC, Coyne MS and others (2010) Assessing accuracy and utility of satellite-tracking data using Argos-linked Fastloc-GPS. Anim Behav 80: $571-581$

Zar JH (1996) Biostatistical analysis, 3rd edn. Prentice-Hall, Upper Saddle River, NJ

Submitted: January 17, 2012; Accepted: December 10, 2012

Proofs received from author(s): March 21, 2013 